Sekcja druga na temat „Teoretyczny dorobek w zakresie podmiotowej roli ucznia” pracowała w dwóch grupach pod przewodnictwem prof. dr. hab. Grzegorza Michalskiego, dr Magdaleny Malik, prof. dr hab. Władysławy Szulakiewicz i dr Danuty Krześniak-Firlej. W sekcji tej wygłoszono 18 referatów.

Pod hasłem „Tradycja i współczesność w kształceniu nauczycieli” obradowała sekcja trzecia, podzielona z uwagi na dużą liczbę wystąpień (30 referatów) na trzy grupy. Przewodnictwa podjęli się: dr hab. Agnieszka Stopińska-Pająk i dr Justyna Wojniak, dr hab. Grażyna Kempa i dr Ewa Kula, prof. dr hab. Romuald Grzybowski i dr Kazimierz Jurzysta. W pracach tej sekcji wzięła udział Pani prof. dr hab. Kalina Bartnicka.

Dziewiętnastu wystąpieniom w ramach sekcji czwartej, obradującej pod hasłem „Osobowość nauczyciela”, przewodniczyli prof. dr hab. Jadwiga Suchmiel, dr Iwonna Michalska, prof. dr hab. Stefania Walasek oraz dr Jan Ryś.

Tematem wiodącym sekcji piątej było „Czasopiśmiennictwo pedagogiczne wobec współczesnych tendencji w pedagogice”. Obradom, w czasie których wygłoszono 4 referaty, przewodniczyła prof. dr hab. Katarzyna Dormus i dr Agnieszka Wałęga.

Ostatnia, szósta sekcja, zgromadziła 7 referatów pod wspólnym tematem „Nauczycielski ruch związkowy i jego wpływ na kreowanie życia szkolnego". Obradom tej sekcji przewodniczyła prof. dr hab. Katarzyna Dormus oraz dr Edyta Kahl.

Podczas podsumowania obrad przygotowano i odczytano postulat, skierowany do Jego Magnificencji Rektora oraz Senatu Uniwersytetu Pedagogicznego im. Komisji Edukacji Narodowej, następującej treści: Uczestnicy Międzynarodowej Konferencji Naukowej pt. Nauczyciel ,, Szkoły Twórczej” - rzecz o Henryku Rowidzie. W 65. rocznice powołania Uniwersytetu Pedagogicznego w Krakowie postuluja, by krakowski Uniwersytet Pedagogiczny wywiódt swój początek z założonego w 1928 roku w Krakowie Państwowego Pedagogium. W 1946 roku doszło tylko do przemianowania Państwowego Pedagogium w Państwowa Wyższa Szkołę Pedagogiczna. Zgłoszony postulat został przyjęty w jednomyślnym głosowaniu. Postulat podpisany został przez Przewodniczącego Komitetu Naukowego, prof. dr. hab. Jana Krukowskiego oraz Przewodniczącego Komitetu Organizacyjnego, dr. Ryszarda Ślęczkę.

Ewa Kula

Marzena Pękowska

\title{
Sprawozdanie z VII Zjazdu Pedagogicznego „Teoria a praktyka edukacyjna”, Toruń 20-21 września 2010
}

Obrady już VII Zjazdu Pedagogicznego zorganizowanego w ramach działalności Polskiego Towarzystwa Pedagogicznego odbyły się w dniach 20-21 września 2010 r. w Toruniu. Gospodarzem Zjazdu był Wydział Nauk Pedagogicznych Uniwersytetu Mikołaja Kopernika. Rolę Przewodniczącego Komitetu Programowego sprawował prof. dr hab. 
Aleksander Nalaskowski, a pracami komitetu organizacyjnego kierowała prof. UMK, dr hab. Maria Marta Urlińska. Obrady Zjazdu toczyły się pod hasłem „Po życie sięgać nowe...", a jego celem miała być, w intencji organizatorów, dyskusja wokół związków pedagogiki jako nauki oraz praktyki edukacyjnej ze światem zewnętrznym z jego rozlicznymi problemami i dylematami.

Otwarcia Zjazdu dokonał prof. A. Nalaskowski, który powitał uczestników i zaproszonych gości. W imieniu gospodarzy zabrał głos także prezydent Torunia Michał Zaleski. Rektor UMK, prof. dr hab. Andrzej Radzimiński podkreślił w swym przemówieniu różnorodność tematyki, podejmowanej podczas obrad przez przedstawicieli ponad 50 uczelni akademickich z całego kraju. Głos zabrał następnie prof. dr hab. Stefan Kwiatkowski, przewodniczący Komitetu Nauk Pedagogicznych PAN. Tematem jego wystąpienia były zmiany w systemie szkolnictwa, a mianowicie odejście od standardów kształcenia ku efektom uczenia się. Mówca podzielił się swymi wątpliwościami na temat problemów związanych z narzędziami pomiaru efektów uczenia się. Kolejne wystąpienie dotyczyło m.in. formuły przyszłych zjazdów pedagogicznych. Prof. dr hab. Zbigniew Kwieciński, przewodniczący Polskiego Towarzystwa Pedagogicznego, zauważył, że pedagogika zgłębia obecnie wszelkie aspekty rozwoju człowieka, ale też czynniki ten rozwój blokujące. Z. Kwieciński podkreślił, że wychowanie ludzi krytycznie myślących to cel współczesnej pedagogiki. Na koniec mówca zaproponował zmianę formuły przyszłych zjazdów przez zapraszanie gości z czołowych zagranicznych ośrodków naukowych. Z kolei prof. dr hab. Aleksander Nalaskowski, dziekan Wydziału Nauk Pedagogicznych UMK, zwrócił uwagę na rosnącą teoretyzację badań naukowych - stawianie pytań bez oczekiwania odpowiedzi. Zarzucił współczesnej pedagogice brak formułowania podstawowych tez, ideologizowanie. Pedagogika musi być neutralna światopoglądowo. Na koniec głos zabrała w imieniu komitetu organizacyjnego prof. M. Urlińska.

Sesję plenarną otworzył referat prof. Astrid Męczkowskiej-Christiansen „Pedagogika bezdroża w ,świecie bez alternatyw", zawierający szereg krytycznych uwag dotyczących stanu pedagogiki jako dyscypliny naukowej, ale też dziedziny praktycznej, a mianowicie sprzeczności etycznych wyzwań i oczekiwań, związków z polityką i gospodarką. W jej opinii przekonanie, że wychowanie to proces przygotowania do sukcesów na polu zawodowym oraz funkcjonowania w gospodarce opartej na wiedzy to fetyszyzacja wartości rynku. Jej zdaniem wynika to z filozofii neoliberalnej, traktującej edukację jako narzędzie rozwoju, zatem traktując ją czysto instrumentalnie. Owe, globalizacyjne spłaszczenie świata" prowadzi, zdaniem referentki, do pozbawiania człowieka własnej tożsamości. Przerost biurokracji widać też w środowisku naukowym pedagogów. Prof. Męczykowska-Christiansen zaapelowała o powrót do ,pedagogiki romantycznej”, tworzącej nową wizję świata edukacji.

Jako drugi zabrał głos prof. Bogusław Śliwerski („Współczesna myśl pedagogiczna w poszukiwaniu nowych idei i teorii”). Uczony stwierdził, że pedagogik nie musi być nieustanną reinterpretacją świata otaczającego, a podjąć zadanie kreowania nowych idei. Zauważył, że nauka powinna być otwarta, a pedagogika jako dyscyplina różnorodna nie powinna stronić od badań interdyscyplinarnych wobec istniejącej wśród badaczy ją uprawiających ogromnej różnorodności postaw badawczych, często konkurencyjnych wobec 
siebie. O rozwój pedagogiki - edukacji życia, o poszukiwanie nowego języka, pozbywanie się ograniczeń zaapelował także prof. Lech Witkowski („,W obronie życiodajności edukacji"). Mówca stwierdził, że stan szkolnictwa jest dramatyczny, co jego zdaniem wynika z ulegania „terrorowi rynku”, swoistego konsumpcjonizmu.

Poniżej szczególna uwaga zwrócona zostanie na zagadnienia historyczne, z braku możliwości zamieszczenia obszerniejszej formy, ograniczymy się jedynie do zasygnalizowania tematyki pozostałych wystąpień.

Po dyskusji nad wykładami wprowadzającymi, rozpoczęły się obrady w formie sesji tematycznych. Pierwsze trzy sesje odbywały się równolegle. Tematem Sesji I był „Rynek i edukacja: między przedsiębiorczością i wykluczeniem”. Sekcję koordynowali profesorowie L. Witkowski, Mirosław Szymański oraz dr hab. Monika Jaworska-Witkowska. Wygłoszono referaty wprowadzające (prof. Eugenia Potulicka - „Neoliberalizm - rynek - skutki przedsiębiorczości w edukacji” oraz prof. Tadeusz Sławek „Uniwersytet, rozum, użyteczność"), a następnie odbył się panel rektorski, w którym wzięli udział rektorzy uczelni państwowych oraz prywatnych. Głos zabrali tu także zarządzający znanymi wydawnictwami, wydającymi książki z dziedziny pedagogiki - Oficyny Wydawniczej „Impuls” oraz Wydawnictwa „Adam Marszałek”.

Sesja II, koordynowana przez prof. Tomasza Szkudlarka obradowała pod hasłem „Demokracja: zaangażowanie i bierność?". Przyjęto tu formułę dyskusji nad referatami opublikowanymi wcześniej na stronie internetowej Zjazdu. Debatowano m.in. nad rolą kształcenia elitarnego w procesie demokratyzacji i pluralizacji społeczeństwa polskiego po roku 1989 (mgr Anna Kola). Doszukiwano się przyczyn bierności społeczeństwa polskiego wobec mechanizmów demokracji (dr Mariola Gańko-Karwowska), rozprawiano o zaangażowaniu nauczycieli w budowie społeczeństwa obywatelskiego (mgr Karolina Starego).

Sesja III natomiast podjęła wątek nazwany przez organizatorów: „Różnica czy zamęt - imitacja czy swojskość”. Jej koordynatorami byli prof. Maria Czerepaniak-Walczak oraz prof. Zbyszko Melosik. Obrady podzielono na trzy części, z których pierwsza nosiła tytuł „Globalne obywatelstwo czy wieża Babel?”, a dyskutowano w niej o m.in. świadomości międzykulturowej wśród młodzieży akademickiej (dr hab. Jadwiga Kosowska-Rataj), społeczeństwie globalnym (dr Lidia Marek), problemach związanych z tożsamością etniczną, a właściwie z jej zatracaniem (dr Joanna Cukras-Stelągowska). Z kolei, w części drugiej podjęto temat „Między pluralizmem a tęsknotą za normatywnymi rozwiązaniami”. Mówcami byli tu dr Tomasz Gmerek (,Edukacja w Rosji - od socjalizmu do neoliberalizmu"), dr Andrzej J. Puliński (referat dotyczył szkolnictwa w Finlandii, opartego na zasadzie egalitaryzmu), dr Jarema Drozdowicz (mówił na temat systemu Human Terrain), mgr Olga Mazurek-Lipka (referat poświęcony zagadnieniu urynkowienia dyplomu akademickiego w USA), mgr Joanna Nawój-Połoczańska (na temat polityki Unii Europejskie w zakresie doradztwa zawodowego). Referowano także zjawiska popkulturowe, a mianowicie zmienność w modzie uczniowskiej (mgr Maria Serafinowicz), czy też wpływy kultury popularnej wśród imigrantów w Norwegii (mgr Karolina Domagalska-Nowak). Część trzecia („Akademia - swojskość czy zamęt) zebrała referaty dotyczące działań międzykulturowych w stosunkach między uczelniami na poziomie międzynarodowym (dr hab. Zbi- 
gniew Kruszewski), badań nad recepcją poglądów P. Bordieu w polskich badaniach naukowych (dr Renata Wawrzyniak-Beszterda, dr Sylwia Jaskulska, mgr Mateusz Marciniak), stanu i perspektyw w kształceniu menadżerów w Polsce (dr Sławomir Banaszak), działań uczelni wyższych skierowanych na rzecz rozwoju społeczności lokalnej (dr Włodzimierz Olszewski), czy wreszcie badań nad wpływem szkolnictwa wyższego na rozwój osobisty człowieka (dr Katarzyna Kabacińska), czy też całych państw (dr Daria Hejwosz - na przykładzie RPA).

Obrady Sesji IV zatytułowanej Postmodernizm i tradycja koordynowała prof. dr hab. Władysława Szulakiewicz (UMK), a rolę sekretarza pełniła dr Agnieszka Wałęga (UMK). Obrady odbyły się w dwóch formułach: część pierwszą stanowiła sesja plenarna (dwa wykłady połączone z dyskusją), w drugiej części obrady odbyły się w formie trzech sekcji problemowych (wystąpienia uczestników w symultanicznych panelach).

Prof. dr hab. Roman Schulz („Czy pedagogika ma swoje wielkie pytania?”) dokonał analizy szeregu problemów poruszanych przez pedagogikę pod kątem poszukiwania źródła wielkich pytań stawianych przez tę naukę. Podjął również wątek stanu kultury i organizacji społeczeństwa, mankamentów pedagogiki w zakresie ich kształtowania. Zadał też pytanie o znaczenie działalności na wymienionych polach profesorów pedagogiki, których liczbę określił na poziomie 1000 osób.

Prof. Romuald Grzybowski, (,Dziedzictwo edukacyjne przeszłości: balast czy skarbnica wzorów?") stwierdził natomiast, że dorobek edukacyjny dawnych pokoleń to dziedzictwo edukacyjne i nie powinien być umniejszany przez nieuwzględnianie roli mniejszości etnicznych i narodowych. W swym wystąpieniu zaapelował także o zaprzestanie „dewastacji dorobku edukacyjnego polskiego, zwłaszcza po wstąpieniu Polski do Unii Europejskiej”. Podjął wreszcie temat popularyzacji dziedzictwa edukacyjnego, zwłaszcza dorobku Komisji Edukacji Narodowej, wśród nauczycieli.

W dyskusji nad referatami wprowadzającymi w tematykę sesji wzięła udział m.in. prof. Kalina Bartnicka, która podkreśliła, że historia wychowania zachęca do myślenia, zwłaszcza w środowisku akademickim; prof. Bronisław Siemieniecki zauważył natomiast pilną potrzebę umieszczania treści historyczno-edukacyjnych w Internecie, wobec ogólnego kryzysu czytelnictwa.

Po wykładach plenarnych obrady przeniosły się do trzech sekcji problemowych:

Sekcja I: Pedagogika i edukacja w perspektywie postmodernistycznej (moderatorzy: prof. Wiesław Jamrożak oraz prof. Jerzy Kochanowicz).

Sekcja II: Pedagogiczne światopoglądy i projekty - dziedzictwo przeszłości (moderatorzy: prof. Stefania Walasek oraz prof. Grzegorz Michalski).

Sekcja III: Edukacyjne sukcesy i porażki - między tradycją a współczesnością (moderatorzy: prof. Kalina Bartnicka oraz prof. Irena Szybiak).

Obrady Sekcji I otworzył referat prof. W. Jamrożka na temat znaczenia kongresów i zjazdów pedagogicznych dla rozwoju polskiej teorii i praktyki edukacyjnej. Z kolei głos zabrał prof. Grzegorz Karwasz („Post-konstruktywizm a korzenie kulturowe Europy”), który mówił m.in. o szkole jako miejscu konfrontacji zachowania w „stadzie” i pewnymi założeniami teoretycznymi, wypływającymi z tradycji kulturowych Europy. Z kolei prof. B. Siemieniecki („Pedagogika kognitywistyczna - marzenie czy rzeczywistość”) zauwa- 
żył, że zrozumienie rozwoju społecznego oznacza zrozumienie współczesnej i przyszłej pedagogiki. Podzielił się ze słuchaczami swoimi spostrzeżeniami dotyczącymi znaczenia mediów w „społeczeństwie wiedzy”.

Dwóch kolejnych prelegentów obiektem swoich rozważań uczyniło pedagogikę chrześcijańską. Ks. prof. Edward Walewander podjął zagadnienie: „Postmodernizm a pedagogika chrześcijańska", wskazując podobieństwa oraz antagonizmy tych dwóch podejść do edukacji oraz wychowania. Zauważył, że pedagogika postmodernistyczna, z założenia areligijna, uniemożliwia jednostkom przyjęcie postawy transcendentnej. Wskazał też, iż traktowanie wartości i norm jako uogólnionych orientacji umożliwiających interpretację rzeczywistości stoi $\mathrm{w}$ sprzeczności z założeniem pedagogiki chrześcijańskiej o duchowości (umiejętność wartościowania rzeczywistości, wolna wola w podejmowaniu wyborów, szukanie Boga) jako jednym z podstawowych czynników rozwoju. Natomiast prof. Jerzy Kochanowicz w referacie pt.: „Doktryna wczesnego chrześcijaństwa jako przełom w wychowaniu", cofnął się rozważaniami do korzeni pedagogiki chrześcijańskiej. Przyjrzał się formowaniu doktryny chrześcijańskiej w kilku pierwszych wiekach naszej ery, gdy chrześcijaństwo uniezależniało się od judaizmu (lata 100-600). Omówił także implikacje powstającej doktryny dla ówczesnej praktyki wychowawczej i edukacyjnej.

Dr Adrianna Nizińska, wygłaszając referat pt.: „Ponowoczesne rewolty w edukacji dorosłych. Od konstatacji do konsternacji”, podjęła próbę wyznaczenia punktów zwrotnych w andragogice. Odróżniła od siebie procesy nauczania i uczeniu, które wyrażają odmienne sposoby myślenia andragogów o przekazie wiedzy osobom dorosłym. Wskazała, jakim zmianom ulegały i ulegają obecnie założenia dotyczące wiedzy uznawanej za podstawową w edukacji dorosłych - starała się raczej stawiać problemowe pytania, unikając jednoznacznych odpowiedzi na nie.

W referacie pt.: „Wychowanie ekologiczne w okresie polskiego modernizmu” dr Edyta Wolter jako ramy interpretacyjne przyjęła myśl J.G. Pawlikowskiego. Wskazała, w jaki sposób prawidłowo ukształtowana postawa wobec środowiska naturalnego prowadzić może do rozwoju kultury oraz rozwoju społecznego jednostki (np. zaangażowanie obywatelskie). Z perspektywy historycznej przyjrzała się problematyce wychowania ekologicznego - przedmiotem którego jest przyroda, a obejmuje zarówno aktywność poznawczą, praktyczną, jak i emocjonalną (estetyczną).

Prof. Tomasz Biernat, w swoim wystąpieniu poszukiwał odpowiedzi na pytanie „Czy istnieje rodzina ponowoczesna?" Wskazał współczesne tendencje przemian w tradycyjnym, trwałym modelu rodziny (dwoje rodziców heteroseksualnych + dzieci) i powstawanie nowych modeli rodziny na skutek zjawisk takich, jak wzrost liczby rozwodów, rekonstrukcja rodziny itp. Nawiązując między innymi do myśli T. Parsonsa, wskazał, że nowa posmodernistyczna, ponowoczesna rzeczywistość nie jest tożsama z jej opisem, a przemiany w obrębie rodziny wpisują się w szerszy kontekst przemian - dokonującą się współcześnie hybrydyzację (także światopoglądową), która dotyczy różnych aspektów rzeczywistości, np.: czasu, przestrzeni itd.

W wystąpieniu pt. „Zmierzch kształcenia jako implikacja podstawowych założeń późnej nowoczesności”, dr Jan Rutkowski postawił tezę, że współcześnie dochodzi do wy- 
czerpania celu i sensu kształcenia. Zjawisko to rozpatrywał w odniesieniu do teleologicznej wizji świata i nowoczesności. Jako jedno ze źródeł poszukiwania wiedzy praktycznej oraz niechęci wobec kształcenia i kształtowania wskazał dążenie do spełnienia własnego interesu zgodnie z zasadami głoszonymi przez Machiavellego.

Dr Jarosław Horowski w wystąpieniu „O dojrzewaniu do moralności cnoty w kontekście kultury (post)modernistycznej”, podkreślił związek moralności z praktyką. Wskazał, że moralność (cnota) kształtuje się poprzez doświadczanie dobra i w tym kontekście przyjrzał się kulturze współczesnej. Zastanawiał się między innymi, czy i na ile przestrzenią tworzenia cnoty ma szansę być współczesny uniwersytet oraz społeczeństwo, w którym ogłoszono koniec życia wspólnotowego.

W referacie pt.: „Poza opozycją 'postmodernizm-tradycja' - od, wychowania dla przyszłości"” B. Suchodolskiego ku humanistycznej pedagogice alterglobalizmu” dr Andrzej Ciążela zestawił ze sobą dwie koncepcje z różnych, jak się wydaje, porządków. Podkreślił aktualność koncepcji B. Suchodolskiego (w której autor proponuje model zintegrowanego wychowania człowieka przez naukę, technikę i sztukę) oraz jej punkty styczne z ,nowoczesnym" modelem wychowania postulowanym w pedagogice alterglobalistycznej. Obie koncepcje nawołują do wychowania antycypującego - przygotowania młodzieży do zmieniającej się rzeczywistości.

Referat dr Tomasza Leszniewskiego dotyczył kwestii: „Tożsamość w działaniu jako konstruktywny ogląd relacji jednostki ze społeczeństwem”. Autor odwołał się do dwóch elementów znaczących w konstruowaniu pojęcia „tożsamość”. Podkreślił niewystarczalność ujęć ,ppsychologizujących”, w których za kluczowe uznaje się znaczenie autokoncepcji (wyrażonej w twierdzeniu: jestem tym, kim uważam, że jestem...), gdyż pomijają one kontekst społecznego funkcjonowania jednostki.

Do problematyki wojen kulturowych odwołał się mgr Sylwester Zielka w referacie „Kanon lektur jako pole walki między tradycją a postmodernizmem?” Podkreślił, że treść wojen wynikających z odmiennego wartościowania wybranego pola kultury zmienia się, więc odmienne są też ich efekty. $Z$ tej perspektywy przyjrzał się dwóm alternatywnym dyskursom tworzenia kanonu lektur szkolnych: wizji „muzeum” (kanon jako „strażnik tradycji”) oraz wizji „supermarketu” (kanon dostosowany do gustu uczniów - „klientów").

W ostatnim referacie sesji ks. mgr Michał Styczyński podjął temat „Logo-wychowawca w kontekście kultury ponowoczesnej. O wizji nauczyciela Victora Emila Frankla”. Omówił, jakie znaczenie ma implementacja koncepcji Frankla (twórcy logoterapii) dla pedagogii. Uznanie pytania o sens życia za pytanie każdego odpowiedzialnego i dojrzałego człowieka wymaga od nauczyciela (wychowawcy) nieustannej gotowości wspierania uczniów poszukujących odpowiedzi na nie. Jak zauważył referent, zadanie jest o tyle trudne, że pomoc wymaga nie tylko dostrzeżenia problemu, ale też powstrzymania się od wyręczania uczniów na rzecz towarzyszenia im.

Sekcja II skupiła referaty odnoszące się do zagadnień dziejów wychowania i pedagogiki w stuleciu XIX. Wysłuchano tu referatów prof. Krzysztofa Jakubiaka na temat przełomów w rodzinie polskiej i wychowaniu rodzinnym w czasach nowożytnych, prof. S. Walasek na temat znaczenia nauczycieli i działaczy społecznych w kształtowaniu się 
postaw obywatelskich w okresie zaborów. Z kolei ks. Prof. Czesław Kustra przedstawił koncepcję edukacji „kobiety pracującej” autorstwa Jadwigi Zamoyskiej. Zasługi Józefa Dietla dla repolonizacji szkolnictwa krakowskiego i małopolskiego zaprezentowała dr A. Wałęsa, a wątek działań myślicieli galicyjskich na temat szkoły kontynuowała mgr Joanna Falkowska (,Szkoła ostają wychowania narodowego. Projekty myślicieli okresu autonomii galicyjskiej”). W dalszych referatach przybliżono tradycje szkoły Tadeusza Czackiego i Hugona Kołłątaja w II RP (dr hab. Andrzej Szmyt), zagadnienia edukacji dorosłych w okresie międzywojennym w Polsce (dr Tomasz Maliszewski), problematykę rozwoju polskiej myśli pedagogicznej okresu międzywojennego (prof. Janina Kostkiewicz, dr Izabela Stelmasiak), czy też kwestię kryzysu polskiego szkolnictwa powszechnego w okresie lat trzydziestych (prof. G. Michalski). Nie zabrakło również referatów poświęconych wychowaniu religijnemu (mgr Ewa Dybowska, dr Beata Topij-Stempińska) oraz wychowaniu patriotycznemu (prof. Elwira Kryńska).

Tematyka Sekcji III związana była ze współczesnym obrazem szkolnictwa i myśli pedagogicznej. Obrady tej sekcji otworzył referat prof. K. Bartnickiej, dotyczący przemian idei uniwersytetu europejskiego w okresie od XVIII w. do początków obecnego stulecia. Wątek kształcenia uniwersyteckiego wobec wyzwań współczesności podjął dr Rafał Godoń. Z kolei prof. I. Szybiak zreferowała tradycje i współczesność historii oświaty i wychowania w kształceniu pedagogów. Dalsze referaty koncentrowały się wokół szkolnictwa specjalistycznego - wojskowego (dr Jan Ryś), zawodowego (dr Ryszard Ślęczka), oświaty dorosłych (prof. Eleonora Sapia-Drewniak) oraz czytelnictwa i jego roli w walce z wtórnym analfabetyzmem w okresie II RP (dr Iwonna Michalska).

Krzysztof Ratajczak,

Mateusz Marciniak 